\title{
VARIABEL-VARIABEL PENENTU HOLDING PERIODS SAHAM SYARI'AH DI INDONESIA
}

\author{
Fitriyah \\ Yayuk Sri Rahayu
}

\author{
Fakultas Ekonomi Universitas Islam Negeri Maulana Malik Ibrahim Malang \\ Jl. Gajayana No. 50, Tlp 0341-558881, Fax. 0341-558881 \\ e-mail: urannia_uin@yahoo.com, ysrais77@yahoo.com
}

\begin{abstract}
This research was aimed to determine whether the variables bid-ask spread, market value, variance return and dividend payout influence holding period partially and simultaneously and to determine the variables that most influence the holding period of shares of sharia in Indonesia Stock Exchange. The population in this research are the companies listed in the Jakarta Islamic Index over the period 2007 to 2010. Sampling using a purposive sampling technique and number of sample are 10 companies.. The result shows, the variable spreads, market value, variance return, dividend payout ratio simultaneously influence the holding period. While partially, there are two variables that significantly influence the holding period that is spread and dividend payout ratio with a significant negative relationship and the spread has a significant positive relationship to the holding period at a 5\%. And the most influential variable is spread. The final conclusions are on the Indonesia Stock Exchange, investors alleged psychological factor is the factor most be taken into consideration in decisions about withholding or release of a common stock.
\end{abstract}

Keyword: Holding periods, bid ask spread, market value, and variance return

Abstraksi

Penelitian ini bertujuan untuk mengetahui apakah variabel bid-ask spread, market value, varians return dan dividen pay out ratio mempengaruhi holding periods secara parsial dan simultan dan untuk mengetahui variabel yang paling mempengaruhi holding period saham syariah di Bursa Efek Indonesia. Populasi dalam penelitian ini adalah perusahaan yang terdaftar di Jakarta Islamic Index selama periode 2007 sampai 2010. Sampling sebanyak 10 perusahaan ditentukan dengan teknik purposive sampling. Hasil analisis menunjukkan variabel bid-ask spread, market value, varians return dan dividen pay out ratio secara simultan mempengaruhi holding periods. Sedangkan secara parsial, ada dua variabel yang berpengaruh signifikan terhadap holding period yaitu dividen pay out ratio yang signifikan negatif dan bid-ask spread signifikan terhadap holding period pada $\alpha 5 \%$. Dan variabel yang paling berpengaruh adalah bid-ask spread . Kesimpulan terakhir adalah di Bursa Efek Indonesia, diduga faktor psikologis investor merupakan faktor yang paling dipertimbangkan dalam keputusan tentang pemotongan atau pelepasan saham biasa.

Kata Kunci: Holding periods, bid ask spread, market value, dan variance return

Perkembangan pasar modal syariah di Indonesia menunjukkan trend semakin baik yang ditandai dengan maraknya perusahaan yang listing di Jakarta Islamic Index (JII), 
penawaran umum Obligasi Syariah dan juga Reksadana Syariah. Kinerja saham syariah yang terdaftar dalam JII mengalami perkembangan yang cukup mengembirakan. Disamping itu telah diterbitkannya (enam) Fatwa Dewan Syariah Nasional Majelis Ulama Indonesia (DSN-MUI) yang berkaitan dengan industri pasar modal dan lembaga yang berkaitan dengan pasar modal (Bapepam Syariah, Lembaga Pemeringkat Efek Syariah dan Dewan Pengawas Islamic Market/Index), telah memberikan dorongan untuk mengembangkan alternatif sumber pembiayaan yang sekaligus menambah alternatif instrumen investasi halal. Hal ini berimbas pada meningkatnya pertumbuhan ekonomi. Seperti diungkapkan oleh Husnan (2003) bahwa perkembangan pasar modal memiliki peran penting dalam meningkatkan pertumbuhan ekonomi karena pasar modal mempunyai 2 fungsi, yaitu fungsi ekonomi dan fungsi keuangan.

Dalam melaksanakan fungsi ekonomi, pasar modal menyediakan fasilitas untuk mempertemukan dua kepentingan, yaitu pihak yang memiliki kelebihan dana (investor) dan pihak yang memerlukan dana (issuer). Sementara dalam melaksanakan fungsi keuangan, pasar modal menyediakan dana yang diperlukan oleh pihak-pihak yang memerlukan dana, dan pihak yang mempunyai kelebihan dana menyediakan dana tanpa harus terlibat langsung dalam aktiva riil yang diperlukan untuk investasi.

Dalam proses pelaksanaannya (pemindahan dana dari investor kepada issuer), pasar modal Indonesia menggunakan order driven market system dan continous ouction system. Order driven market system artinya pasar digerakkan oleh order-order dari pialang dengan sistem lelang secara terus-menerus. Investor tidak dapat secara langsung melakukan transaksi di lantai bursa dan hanya seorang broker yang dapat melakukan transaksi jualbeli di lantai bursa berdasarkan perintah atau instruksi dari investor.

Sedangkan continous auction system atau yang biasa disebut dengan sistem lelang kontinyu adalah bahwa harga transaksi yang terjadi atas suatu saham tertentu ditentukan oleh tingkat penawaran (supply) dan tingkat permintaan (demand) dari para investor. Bagi calon investor mengajukan instruksi beli kepada broker untuk melakukan pembelian atas saham tertentu dengan harga, jumlah, jenis order dan jenis saham yang ditentukan oleh investor. Demikian juga untuk order beli, cara yang sama akan diterapkan oleh investor.

Di dalam proses jual beli saham dan menahan kepemilikan saham untuk jangka waktu tertentu dan kemudian menjualnya, investor akan mempertimbangkan return dan risikonya. Investor akan memutuskan kapan saham tersebut akan dijual agar memperoleh return yang diharapkan. Semakin lama investor memutuskan untuk menjual sahamnya berarti semakin lama investor akan menahan saham tersebut. Lamanya jangka waktu 
investor menahan saham dari saham tersebut dibeli sampai dijual kembali disebut holding period.

Atkins dan Dyl (1997) menemukan bahwa holding period saham dipengaruhi secara signifikan oleh transaction cost yang dicerminkan oleh bid-ask spread, , market value dan variance return. Menurut Yenny, Iramani dan Linda (2003) yang dikutip dari teori Mendelson (1986), ada 2 faktor yang mempengaruhi lamanya holding period saham seorang investor yaitu : Faktor Eksternal (inflasi) dan Faktor Internal (transaction cost: bid-ask spread, market value dan risk of return saham). Bid-ask spread merupakan selisih antara beli (bid) terendah yang menyebabkan investor bersedia untuk membeli saham tertentu dengan harga jual (ask) tertinggi yang menyebabkan investor bersedia untuk menjual sahamnya. Nilai pasar saham (market value) menunjukkan nilai sebuah perusahaan semakin besar market value suatu perusahaan, makin lama pula investor akan menahan kepemilikan sahamnya atau semakin lama pula holding period sahamnya.

Variabel lain yang diduga berpengaruh terhadap holding period investor terhadap saham biasa adalah kebijakan dividen (dividend policy) perusahaan, dalam hal ini dividend pay out ratio. Penelitian yang dilakukan oleh, Akhigbe dan Madura (1996), Mitra dan Rasyid (1997), Maulina (2010) membuktikan adanya hubungan negatif signifikan antara kebijakan dividen dengan bid-ask spread yang berarti saham-saham perusahaan yang membagikan dividen akan lebih liquid dibandingkan dengan perusahaan yang tidak membagikan dividen. Jika hal ini dikaitkan dengan penelitian yang dilakukan Suharsono (1999) bahwa keputusan pembelian saham di kalangan investor lokal dipengaruhi oleh faktor motif pembelian saham, dan di antara motif pembelian saham yang paling banyak mewarnai adalah motif pendapatan yaitu investor mengharap penghasilan dari dividen yang memadai, sehingga dengan kebijakan dividen yang dilakukan diharapkan investor akan memegang/menahan sekuritas tersebut dalam jangka waktu pendek/panjang.

Penelitian ini menguji kembali konsistensi penelitian sebelumnya terhadap terhadap variabe-variabel bid - ask spread, market value, variance return, dan dividend pay out serta pengaruhnya terhadap holding periods saham syariah di Bursa Efek Indonesia. Perbedaan penelitian ini dengan penelitian sebelumnya adalah pada sampel penelitian. Pada penelitian sebelumnya umumnya menggunakan sampel saham biasa (konvensional). Dengan karakteristik khusus yang dimiliki saham syariah (saham emiten harus memenuhi prinsip-prinsip dasar syariah) maka peneliti tertarik untuk menguji variabel yang berpengaruh terhadap holding period saham Syariah di Bursa Efek Indonesia.

\section{Bid-Ask Spread}


Menurut Hamilton dalam Maulina (2010) terdapat tiga faktor yang dapat mempengaruhi besarnya spread yaitu cost (cost of transaction immediacy to investor), informasi (market making cost) dan kompetisi (interdealer competition). Cost (biaya) muncul sebagai konsekuensi dari transaksi yang dilakukan broker atas permintaan investor. Spread berhubungan terbalik dengan jumlah aktivitas perdagangan saham. Saham yang lebih banyak aktivitas perdagangannya (yaitu, volume perdagangan) cenderung memiliki spread yang rendah. Hubungan yang terbalik antar jumlah aktivitas perdagangan (atau nilai pasar) dan ukuran spread dapat dijelaskan dengan segera setelah diketahui bahwa spread yang ada adalah kompensasi bagi dealer yang memberikan investor likuiditas. Semakin kecil jumlah perdagangan, semakin jarang dealer akan memperoleh spread. Jadi dealer akan memerlukan spread yang memadai bagi sekuritas yang lebih sering diperdagangkan. (Sharpe, 2005)

Corrado dan Jordan (2000) mengemukakan bahwa bid-ask spread merupakan ukuran laba kotor yang diinginkan dealer dari suatu transaksi pembelian pada bid price dan pennjualan pada ask price. Bid price adalah harga tertinggi yang ditawarkan oleh dealer atau harga dimana spesialis atau dealer menawar untuk membeli saham-saham. Sedangkan ask price adalah harga terendah dimana dealer bersedia untuk menjual atau harga dimana spesialis ataudealer menawar untuk menjual saham-saham (Jones, 1996). Bid-ask spread dari dealer (broker) kemudian diturunkan kepada investor, artinya biaya dan tingkat kompensasi yang diinginkan oleh dealer sebagai perantara perdagangan di bursa efek dibebankan kepada investor selaku nasabah dealer.

\section{Market Value}

Nilai pasar saham merupakan harga saham yang terjadi di pasar bursa pada saat tertentu akibat aktivitas transaksi di pasar bursa (mekanisme pasar). Nilai pasar saham ini merupakan cerminan besarnya ukuran perusahaan yang dihitung dengan mengalikan jumlah saham beredar dengan harga pasar saham. Asset size yang mencerminkan atau sebagai pengukur besarnya perusahaan mempunyai hubungan negative dengan tingkat resiko portofolio relatif terhadap resiko pasar, yang berarti bahwa perusahaan besar dianggap mempunyai resiko yang lebih kecil jika dibandingkan dengan perusahaan kecil. Hal ini terjadi karena perusahaan besar dianggap lebih mempunyai akses ke pasar modal, sehingga dianggap mempunyai resiko yang lebih kecil. (Jogiyanto, 1998).

Berdasarkan penelitian Atkins dan Dyl(1997) diatas diperoleh kesimpulan bahwa bid-ask spread, market value, dan return saham mempengaruhi frekuensi perdagangan dan 
menyebabkan investor mengharapkan untuk menahan lebih panjang atau pendek asset yang memiliki spread besar. Nilai pasar saham (market value) menunjukkan nilai sebuah perusahaan semakin besar market value suatu perusahaan, makin lama pula investor akan menahan kepemilikan sahamnya atau semakin lama pula holding period sahamnya.

\section{Variance Return}

Return total merupakan return keseluruhan yang akan diperoleh dari suatu kegiatan investasi dalam suatu periode tertentu. Return total terdiri dari capital gain (loss) dan yield.(Jogiyanto, 2003). Variance return menunjukkan variabilitas return di seputar return normal yang diakibatkan adanya volatilitas (fluktuasi harga) saham. Semakin tinggi variance return menunjukkan semakin bervariasinya return harian yang diperoleh investor. Hal ini mencerminkan ketidakpastian (resiko) pasar yang tinggi.

Dalam kaitannya dengan pertimbangan investasi khususnya keputusan untuk menahan atau melepas suatu kepemilikan saham, return dan tingkat resiko merupakan bahan pertimbangan tambahan yang dapat digunakan dalam pengambilan keputusan karena pada dasarnya antara tingkat resiko yang harus ditanggung dengan penentuan waktu untuk keputusan menahan atau melepas saham merupakan suatu hal yang berkaitan.

\section{Kebijakan Dividen}

Dividen merupakan bagian dari keuntungan perusahaan yang didistribusikan kepada para pemegang saham dan pada umumnya dilakukan secara berkala baik dalam bentuk uang kas atau yang lainnya, misalnya dividen saham (stock dividend) dan dividen extra (extra dividend). Sedangkan yang dimaksud kebijakan dividen sendiri adalah keputusan menajemen apakah laba yang diperoleh perusahaan akan dibagikan kepada pemegang saham sebagai dividen atau akan ditahan dalam bentuk laba ditahan guna pembiayaan investasi di masa dating. Apabila suatu perusahaan memilih untuk membagikan laba sebagai dividen, maka akan mengurangi laba yang ditahan dan juga mengurangi total sumber dana intern atau internal financing. Sebaliknya jika perusahaan memilih untuk menahan laba yang diperoleh, maka kemampuan pembentukan dana intern akan semakin besar.

Teori sinyal-sinyal dividen (Miller dan Rock, 1985) menyatakan bahwa dividen menyampaikan informasi tentang ekspektasi-ekspektasi manajer dengan memperhatikan arus kas perusahaan, maka informasi yang dikandung dividen mengurangi informasi asimetris. Regularitas perusahaan dalam mempublikasikan pembayaran dividendividennya menunjukkan arus informasi yang periodik, meskipun dilakukan dalam 
kuantitas dan kualitas yang berbeda. Karena itulah, informasi yang terkandung dalam kebijakan dividen akan menghasilkan informasi asimetris di tingkat yang lebih rendah daripada tidak membayarkan dividen.

\section{Holding Period}

Holding Period adalah lamanya waktu yang diperlukan investor untuk berinvestasi dengan sejumlah uang yang bersedia dikeluarkan. Holding Period juga berarti rata-rata panjangnya waktu investor menahan saham perusahaan selama jangka waktu atau periode tertentu (Jones,1996). Menurut Atkin dan Dyl (1997) rata-rata holding period seorang investor untuk periode tertentu di hitung dengan cara membagi jumlah saham beredar pada tahun $t$ dengan volume perdagangan saham pada tahun $t$.

Investor akan menahan/memiliki aset lebih lama jika aset tersebut memiliki transaction cost yang lebih tinggi (Amihud dan Mendelson, 1986). Jika investor memprediksikan bahwa saham perusahaan yang dibelinya tersebut dapat menguntungkan, maka investor akan cenderung menahan sahamnya dalam jangka waktu yang lebih lama, tentunya dengan harapan bahwa harga jual saham tersebut akan lebih tinggi dimasa yang akan datang. Sebaliknya, investor akan segera melepas saham yang telah dibelinya, jika diprediksikan bahwa harga saham tersebut akan mengalami penurunan. Hal ini dilakukan oleh para investor untuk meminimalkan resiko yang akan di hadapinya.

\section{Hipotesis}

Berdasarkan landasan teori dan hasil penelitian terdahulu maka dapat dirumuskan hipotesis sebagai berikut :

H.1 : Diduga bid-ask spread mempunyai pengaruh positif signifikan terhadap holding period saham syariah yang tercatat dalam Jakarta Islamic Indeks (JII)

H.2 : Diduga market value mempunyai pengaruh positif signifikan terhadap holding period saham syariah yang tercatat dalam Jakarta Islamic Indeks (JII)

H.3 : Diduga dividen pay out ratio mempunyai pengaruh positif signifikan terhadap holding period saham syariah yang tercatat dalam Jakarta Islamic Indeks (JII)

H.4 : Diduga variance return mempunyai pengaruh negatif signifikan terhadap holding period saham syariah yang tercatat dalam Jakarta Islamic Indeks (JII)

H5 : Diduga bid-ask spread, market value, variance return dan dividend pay out ratio secara bersama-sama mempunyai pengaruh terhadap holding period saham syariah yang tercatat dalam Jakarta Islamic Indeks (JII).

\section{METODE}


Penelitian ini menggunakan rancangan penelitian penjelasan (explanatory) yang menjelaskan hubungan kausal antara variabel-variabel penelitian melalui pengujian hipotesis. Sedangkan karakteristik penelitian ini bersifat extended replication yang merupakan pengembangan dari penelitian terdahulu.

Populasi dalam penelitian ini meliputi perusahaan yang termasuk dalam Jakarta Islamic Indeks selama periode tahun 2007 - 2010. Pengambilan sampel menggunakan teknik purposive sampling. Adapun nama-nama perusahaan yang telah membukukan laporan keuangan dan masuk dalam Jakarta Islamic Index (Tahun 2007 - 2010) adalah:

\begin{tabular}{ll} 
No & \multicolumn{1}{c}{ Nama Perusahaan } \\
1. & Astra Agro Lestari Tbk (AALI) \\
2. & Aneka Tambang (Persero) Tbk (ANTM) \\
3. & International Nickel Indonesia Tbk (INCO) \\
4. & Indocement Tunggal Prakasa Tbk (INTP) \\
5. & Kalbe Farma Tbk (KLBF) \\
6. & Tambang Batubara Bukit Asam Tbk (PTBA) \\
7. & Semen Gresik (Persero) Tbk (SMGR) \\
8. & Timah Tbk (TINS) \\
9. & Telekomunikasi Indonesia Tbk (TLKM) \\
10. & Unilever Indonesia Tbk (UNVR)
\end{tabular}

Selaras dengan perumusan masalah dan hipotesis, maka variabel-variabel yang akan dianalisis dikelompokkan menjadi dua bagian yaitu:

a. Dependent Variable atau Variabel Terikat berupa holding period

Holding Period adalah rata-rata panjangnya waktu yang digunakan investor dalam menyimpan/memegang suatu sekuritas selama periode waktu tertentu. Rata-rata holding period investor untuk setiap tahun dihitung dengan membagi jumlah saham beredar (share outstanding) dengan volume perdagangan saham i tahun ke $\mathrm{t}$ (Atkins dan Dyl, 1997).

$\mathrm{HP}_{\mathrm{it}}=\frac{\text { Saham Beredar Tahun ke-t }}{\text { Volume Perdagangan Tahun ke-t }}$

b. Independent Variable atau Variabel Bebas merupakan variabel yang diduga berpengaruh terhadap variabel terikat, terdiri dari:

1. Variabel X1 : bid-ask spread

Spread adalah perbedaan harga tertinggi yang dibayarkan oleh seorang pembeli dengan harga terendah yang bersedia ditawarkan oleh penjual. Konsep perhitungan spread adalah dengan membuat rata-rata bid-ask spread harian untuk tiap jenis saham yang diteliti selama periode observasi. Dengan mengacu pada penelitian Atkins dan Dyl (1997) spread dirumuskan sebagai berikut : 
Spread $_{\mathrm{it}}=\left[\sum_{t=1}^{N} \frac{a s k_{i t}-b_{i d}}{\left(a s k_{i t}+b i d_{i t}\right) / 2}\right] / \mathrm{N}$

Dimana:

Spread $_{\text {it }}$ : rata-rata presentase bid ask spread dari saham $i$, pada tahun $\mathrm{T}$

$\mathrm{N} \quad$ : jumlah pengamatan selama satu tahun

Ask $_{\mathrm{it}} \quad$ : Harga jual terendah yan menyebabkan investor setuju untuk menjual saham $i$ pada hari $t$

Bid $_{i t} \quad$ : Harga beli terendah yan menyebabkan investor setuju untuk menjual saham $i$ pada hari $t$

2. Variabel X2 : variance return

Variance return adalah tingkat resiko yang terjadi dari suatu kegiatan investasi, terutama akibat transaksi saham di pasar bursa yang disebabkan adanya volatilitas harga saham. Rata-rata Return saham dihitung dengan menggunakan rata-rata aritmatika dari data harian selama periode observasi. (Fabozzi, 2000). Variance return dirumuskan sebagai berikut:

$$
\begin{aligned}
& \mathbf{R}_{\mathbf{i t}}=\left[\frac{\left(P_{t}-P_{t-1}\right)}{P_{t-1}}\right] \\
& \mathbf{R A}=[\mathrm{R} 1+\mathrm{R} 2+\mathrm{R} 3+\ldots+\mathrm{Rm}] / \mathrm{m} \\
& \text { Variance }=\frac{n \sum x^{2}-\left(\sum x\right)^{2}}{n(n-1)}
\end{aligned}
$$

3. Variabel X3 : market value

Market value adalah harga saham yang terjadi di pasar pada saat tertentu yang di tentukan oleh pelaku pasar, yaitu merupakan rata-rata harga saham selama satu tahun dikalikan dengan jumlah saham beredar per akhir tahun. Mengacu penelitian Atkin dan Dyl (1997) market value dirumuskan sebagai berikut:

\left.${\text { Mkt } \operatorname{Val}_{i T}=[\text { [harga saham }}_{\mathrm{iT}}\right] \times$ jumlah saham beredar $_{\mathrm{iT}}$

$$
\mathrm{N}
$$

4. Variabel X4 : dividen pay out ratio

Adalah jumlah dividen - dividen yang telah dibayar pada tahun tersebut dibagi dengan laba per lembar saham pada akhir tahun. (Brigham, 2006).

Dividend Pay Out Ratio $=$ Devidend per share

Earning per share

\section{Metode Analisis Data}


Pengujian hipotesis menggunakan analsis regresi untuk mengetahui pengaruh antara variabel independen (bid-ask spread, variance return, market value, dan dividend pay out ratio) terhadap variabel dependen (holding period). Analisis regresi yang dilakukan dalam pengujian ini adalah model analisis regresi berganda kwadrat terkecil dua tahap dengan terlebih dahulu melakukan analisis kausalitas antara variabel holding period dan bid-ask spread. Dari pengujian kausalitas yang bersifat simultan tersebut, jika dihasilkan kesimpulan menerima $\mathrm{H}_{\mathrm{o}}$ maka pengujian akan dilakukan menggunakan analisis regresi dengan model ordinary least square (OLS). Tatapi jika dihasilkan kesimpulan hubungan kausalitas maka pengujian dilakukan menggunakan regresi dengan model twostage least square (TSLS).

Dari penelitian yang telah dilakukan, pengujian hubungan kausalitas antara holding periods dengan bid - ask spread dilakukan menggunakan pengujian dua arah. Berdasarkan hasil kesimpulan pada pengujian arah pertama dan kedua maka dapat disimpulkan bahwa tidak terjadi hubungan kausalitas atau dua arah yang saling mempengaruhi secara bersamaan. Sehingga dengan dasar kesimpulan ini maka untuk pengujian analisis selanjutnya menggunakan analisis regresi dengan model ordinary least square (OLS). Model matematis yang dari penelitian ini adalah:

$$
Y=\beta_{t}+\beta_{1} X_{1}++\beta_{2} X_{2}+\beta_{3} X_{3}+\beta_{4} X_{4}+e
$$

\section{HASIL DAN PEMBAHASAN}

\section{Analisis Pengujian Hubungan Kausalitas}

Pengujian hubungan kausalitas antara holding periods dengan bid - ask spread dilakukan menggunakan pengujian dua arah. Berdasarkan hasil kesimpulan pada pengujian arah pertama dan kedua maka dapat disimpulkan bahwa tidak terjadi hubungan kausalitas atau dua arah yang saling mempengaruhi secara bersamaan (seperti pada tabel). Sehingga dengan dasar kesimpulan ini maka untuk pengujian analisis selanjutnya menggunakan analisis regresi dengan model ordinary least square (OLS).

Tabel 1.

Uji satu arah variabel $\operatorname{Spread}_{t}$ dan Holding $_{t-1}$ dan $_{\text {spread }}$ t-1 $_{1}$

\begin{tabular}{|c|c|c|c|c|c|c|}
\hline \multicolumn{7}{|c|}{ ANOVA $A^{b}$} \\
\hline \multicolumn{2}{|c|}{ Model } & $\begin{array}{l}\text { Sum of } \\
\text { Squares }\end{array}$ & df & Mean Square & $\mathrm{F}$ & Sig. \\
\hline \multirow[t]{3}{*}{1} & Regression & .000 & 2 & .000 & 1.580 & $.224^{a}$ \\
\hline & Residual & .003 & 27 & .000 & & \\
\hline & Total & .003 & 29 & & & \\
\hline
\end{tabular}




\section{Analisis Regresi}

\section{Hasil Uji Estimasi Regresi Sebelum Uji Asumsi Klasik}

Setelah dilakukan perhitungan dengan program SPSS for Windows versi 11.5 terhadap data yang telah ditentukan dalam penelitian maka fungsi persamaannya adalah:

$\mathrm{Y}=1060.9309567 .794 \mathrm{X} 1+4042.994 \mathrm{X} 2+2.829 \mathrm{E}-13 \mathrm{X} 3-1.516 \mathrm{X} 4+\mathrm{e}$

Hasil estimasi regresi menunjukkan tidak ada variabel yang signifikan yang

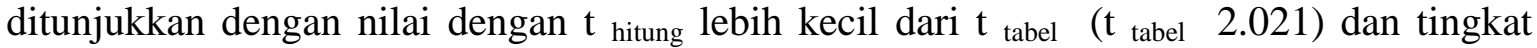
signifikansi diatas $\alpha=5 \%$. Sehingga perlu dilakukan pengujian asumsi sesuai dengan kaidah yang berlaku untuk mendeteksi apakah terdapat pelanggaran asumsi ekonometrika (asumsi klasik) pada data variabel penelitian.

\section{Pengujian Asumsi Klasik}

\section{Uji Normalitas}

Tabel 2.

Uji Normalitas Distribusi terhadap Variabel -variabel bid-ask spread(X1), variance return (X2), market value $(\mathrm{X} 3)$, dan dividend pay out ratio $(\mathrm{X} 4)$

\begin{tabular}{|c|c|c|c|c|c|c|}
\hline \multicolumn{7}{|c|}{ One-Sample Kolmogorov-Smirnov Test } \\
\hline & & HOLDING & SPREAD & VARIAN & MARKET & DPR \\
\hline $\mathrm{N}$ & & 40 & 40 & 40 & 40 & 40 \\
\hline \multirow[t]{2}{*}{ Normal Parameters a,b } & Mean & 4,2672 &, 03687421 &, 00125914 & $6,5 \mathrm{E}+13$ & 55,2601 \\
\hline & Std. Deviation & 5,03054 & $\star * \star * \star * \star \star *$ & $\star * * * * * * * *$ & $1,0 \mathrm{E}+14$ & 81,88632 \\
\hline Most Extreme & Absolute & ,254 & ,123 & ,229 & ,286 & ,321 \\
\hline \multirow[t]{2}{*}{ Differences } & Positive & ,254 & 123 & 229 & 275 & ,321 \\
\hline & Negative &,- 208 &,- 084 &,- 185 &,- 286 &,- 268 \\
\hline Kolmogorov-Smirnov Z & & 1,607 & ,776 & 1,451 & 1,808 & 2,030 \\
\hline Asymp. Sig. (2-tailed) & &, 011 &, 584 & ,030 & ,003 & 001 \\
\hline
\end{tabular}

Hasil pengujian menunjukkan nilai K-S untuk variabel dependen (holding periods) sebesar 1.607 dengan probabilitas signifikansi .011 nilai ini kurang $\alpha=0.05$. Hal ini berarti variabel holding periods tidak terdistribusi secara normal. Sedangkan untuk variabel independen yang terdistribusi normal yaitu bid-ask spread(X1) yang ditunjukkan dengan angka K-S .776 pada probabilitas signifikansi .584. Untuk variabel independen yang lain yaitu, variance return (X2), market value (X3), dan dividend pay out ratio(X4) tidak terdistribusi secara normal dengan angka probabilitas kurang dari $\alpha=0.05$.

Untuk dapat mempergunakan model regresi maka data yang digunakan harus berdistribusi normal. Untuk mengatasi data tidak normal, ada beberapa cara yang dapat dilakukan yaitu dengan melakukan trasformasi dan mendeteksi adanya data outlier. Dalam 
penelitian ini, terlebih dahulu akan dilakukan transformasi data dalam angka ln dari variabel tidak normal yang telah diabsolutkan.

Adapun hasil pengujian data logaritma ditunjukkan pada tabel 3 berikut:

\section{Tabel 3.}

Uji Normalitas Distribusi terhadap Variabel -variabel bid-ask spread(X1), variance return (X2), market value (X3), dan dividend pay out ratio(X4)

(data dalam bentuk ln)

One-Sample Kolmogorov-Smirnov Test

\begin{tabular}{|c|c|c|c|c|c|c|}
\hline & & INHOLDTH & LNSPREAD & LNVARIAN & LNMARKET & LNDPR \\
\hline \multirow{3}{*}{ Normal Parameters $\mathrm{a}, \mathrm{b}$} & & 40 & 40 & 40 & 40 & 40 \\
\hline & Mean & 6,1906 & $-3,3370$ & $-7,8624$ & 31,2840 & 3,5551 \\
\hline & Std. Deviation & ,85220 & 27308 & 3,05344 & ,92865 & 88442 - - 1 \\
\hline \multirow{3}{*}{$\begin{array}{l}\text { Most Extreme } \\
\text { Differences }\end{array}$} & Absolute & 167 & 115 & ,361 & 135 & 109 \\
\hline & Positive & ,062 & 115 & 183 & 135 & 109 \\
\hline & Negative &,- 167 &,- 070 &,- 361 &,- 085 &,- 078 \\
\hline Kolmogorov-Smirnov Z & & 1,055 &, 725 & 2,285 & ,851 & ,692 \\
\hline Asymp. Sig. (2-tailed) & & ,216 & ,669 & ,224 & ,464 & ,724 \\
\hline
\end{tabular}

Dari tabel 3 diatas menunjukkan nilai Kolmogorov Smirnov Test (K-S) terlihat bahwa semua variabel sudah menunjukkan distribusi yang normal, ditunjukkan dengan nilai K-S masing-masing variabel baik dependen maupun independen dan probabilitas signifikansi diatas, yang berarti data terdistribusi normal. Hal ini juga dapat dibuktikan secara grafik sebagai berikut :

Normal P-P Plot of Regres

Dependent Variable: INHC

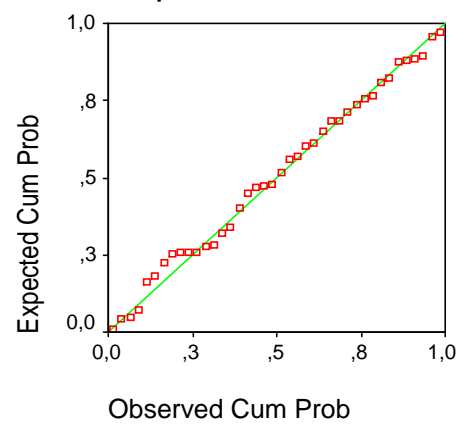

Gambar P-P Plot

Gambar diatas menunjukkan bahwa data bergerombol disekitar garis uji yang mengarah ke kanan atas, tidak ada gerombolan plot data yang terletak jauh dari garis uji normalitas. Dengan demikian data tersebut bisa dikatakan mempunyai sebaran yang normal atau dengan kata lain telah memenuhi asumsi normalitas sebaran data.

\section{Uji Non Autokorelasi}

Tabel 4.

Uji Autokorelasi terhadap Variabel -variabel bid-ask spread(X1), variance return (X2), market value (X3), dan dividend pay out ratio(X4) 


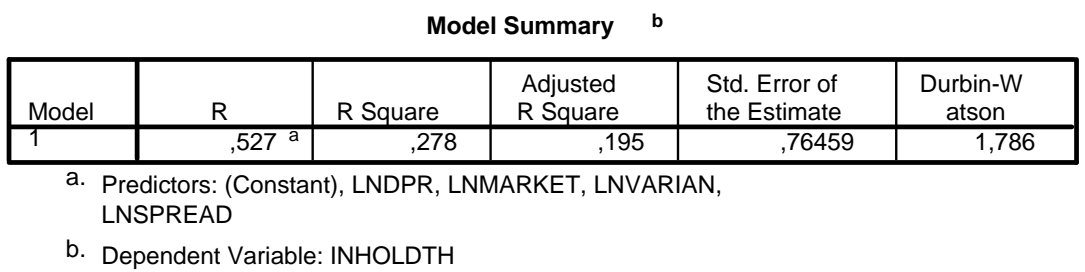

Dari hasil pengujian Durbin Watson menunjukkan dw 2.036 lebih besar dari batas atas (du) 1.720 dan kurang dari 4-1.739, maka dapat disimpulkan tidak ada korelasi serial diantara disturbance terms, sehingga variabel tersebut independen (tidak ada autokorelasi).

\section{Heteroskedastisitas}

Tabel 5

Uji Heteroskedastisitas terhadap Variabel -variabel bid-ask spread(X1), variance return (X2), market value $(\mathrm{X} 3)$, dan dividend pay out ratio $(\mathrm{X} 4)$

Coefficientsa

\begin{tabular}{|ll|r|r|r|r|r|}
\hline \multirow{2}{*}{ Model } & \multicolumn{2}{|c|}{$\begin{array}{c}\text { Unstandardized } \\
\text { Coefficients }\end{array}$} & \multicolumn{2}{c|}{$\begin{array}{c}\text { Standardized } \\
\text { Coefficients }\end{array}$} & & \multirow{2}{*}{} \\
\cline { 3 - 5 } & & \multicolumn{1}{|c|}{$\mathrm{B}$} & \multicolumn{1}{c|}{ Std. Error } & \multicolumn{1}{c|}{ Beta } & \multicolumn{1}{c|}{ Sig. } \\
\hline 1 & (Constant) & 3,807 & 2,303 & & 1,653 &, 107 \\
& LNSPREAD &, 636 &, 269 &, 405 & 2,368 &, 235 \\
& LNVARIAN &, 019 &, 023 &, 134 &, 823 &, 416 \\
& LNMARKET &,- 018 &, 074 &,- 039 &,- 244 &, 809 \\
& LNDPR &,- 111 &, 081 &,- 229 & $-1,376$ &, 177 \\
\hline
\end{tabular}

a. Dependent Variable: ABSUT

Dari hasil analisis SPSS dengan jelas menunjukkan tidak ada satu pun variabel independen yang signifikan secara statistik mempengaruhi variabel dependen nilai Absolut Residual. Al ini terlihat dari probabilitas signifikansi di atas $\alpha=0.05$. Jadi dapat disimpulkan model regresi tidak mengandung adanya heteroskedastisitas.

\section{Uji Multikolinearitas}

\section{Tabel 6}

Uji Multikolinearitas terhadap Variabel -variabel bid-ask spread(X1), variance return (X2), market value (X3), dan dividend pay out ratio(X4)

\begin{tabular}{|c|c|c|c|c|c|c|c|c|}
\hline \multicolumn{9}{|c|}{ Coefficients $^{a}$} \\
\hline \multirow{2}{*}{\multicolumn{2}{|c|}{ Model }} & \multicolumn{2}{|c|}{$\begin{array}{c}\text { Unstandardized } \\
\text { Coefficients }\end{array}$} & \multirow{2}{*}{$\begin{array}{c}\begin{array}{c}\text { Standardized } \\
\text { Coefficients }\end{array} \\
\text { Beta }\end{array}$} & \multirow[b]{2}{*}{$t$} & \multirow[b]{2}{*}{ Sig. } & \multicolumn{2}{|c|}{ Collinearity Statistics } \\
\hline & & $\mathrm{B}$ & Std. Error & & & & Tolerance & VIF \\
\hline \multirow[t]{5}{*}{1} & (Constant) & 2,334 & 4,252 & &, 549 &, 587 & & \\
\hline & LNSPREAD & 1,029 & ,496 & 330 & 2,076 &, 045 & 818 & 1,223 \\
\hline & LNVARIAN & ,009 & ,042 & ,034 & ,222 & ,826 & ,906 & 1,104 \\
\hline & LNMARKET & ,051 & ,137 & ,055 & ,370 & ,714 & ,928 & 1,078 \\
\hline & LNDPR &,- 306 & 149 &,- 318 & $-2,052$ & ,048 & ,860 & 1,163 \\
\hline
\end{tabular}

a. Dependent Variable: INHOLDTH 
Dari tabel tersebut di atas dapat disimpulkan bahwa untuk setiap variabel bebas tidak terjadi multikolineritas dengan ditunjukkan nilai VIF dari setiap variabel bebas yang lebih kecil dari 10.

\section{Analisis Regresi Linier Berganda}

Dalam pengolahan data dengan menggunakan regresi linear, dilakukan beberapa tahapan untuk mencari hubungan antara variabel dependen (holding periods (Y)) dan variabel independen bid-ask spread(X1), variance return (X2), market value (X3), dan dividend pay out ratio(X4). Model regresi berdasarkan hasil analisis di atas adalah:

$$
\mathrm{Y}=.2341+1.029 \mathrm{X} 1+.009 \mathrm{X} 2+.051 \mathrm{X} 3-.306 \mathrm{X} 4+\mathrm{e}
$$

Persamaan tersebut menunjukkan angka yang signifikan pada variabel bid-ask spread(X1) dan dividend pay out ratio(X4), namun arah koefisiennya menunjukkan perbedaan yaitu positif dan negatif. Sedangkan variance return (X2), market value (X3) tidak signifikan.

\section{Uji Pengaruh secara Simultan}

Untuk menunjukkan apakah semua variabel independen yang dimasukkan dalam model mempunyai pengaruh signifikan secara bersama-sama terhadap variabel dependen maka digunakan uji F. Berikut ini adalah tabel yang menunjukkan hasil uji $\mathrm{F}$ dan besarnya $\mathrm{F}$ tabel dengan degree of freedom (df) 5.

Tabel 7.

\section{Hasil Pengujian Hipotesis secara Simultan}

ANOVA

\begin{tabular}{|rl|r|r|r|r|r|}
\hline \multicolumn{1}{|c|}{} & \multicolumn{1}{c|}{$\begin{array}{c}\text { Sum of } \\
\text { Model }\end{array}$} & Squares & df & Mean Square & F & Sig. \\
\hline 1 & Regression & 7,863 & 4 & 1,966 & 3,362 &, $020^{\mathrm{a}}$ \\
& Residual & 20,461 & 35 &, 585 & & \\
& Total & 28,323 & 39 & & & \\
\hline
\end{tabular}

a. Predictors: (Constant), LNDPR, LNMARKET, LNVARIAN, LNSPREAD

b. Dependent Variable: INHOLDTH

Dari tabel 7 di atas diketahui bahwa ada pengaruh secara serentak ditunjukkan dengan besarnya $F$ hitung sebesar 3.362. Nilai ini lebih besar dari F tabel $(2.849>2.61)$. Hal ini menunjukkan bahwa terdapat pengaruh yang signifikan dari variabel bid-ask spread (X1), variance return (X2), market value (X3), dan dividend pay out ratio(X4) terhadap holding period (Y). Dengan demikian pengujian menunjukkan H 1 diterima.

\section{Uji Pengaruh secara Partial}

Untuk menunjukkan apakah variabel independen secara individu mempunyai 
pengaruh yang signifikan terhadap variabel dependen serta untuk membuktikan variabel manakah yang paling dominan maka digunakan uji t dan koefisien beta yang telah distandarisasi. Berikut ini adalah tabel yang menunjukkan hasil uji t dan besarnya t tabel pada signifikansi $5 \%$ dua sisi :

Tabel 8.

Hasil Pengujian Hipotesis Secara Partial

\begin{tabular}{|l|l|l|}
\hline \multicolumn{1}{|c|}{ Pernyataan } & Nilai & Keterangan \\
\hline $\begin{array}{l}\text { Variabel bid-ask spread berpengaruh positif } \\
\text { signifikan terhadap holding period saham (Y) }\end{array}$ & $\begin{array}{l}\mathrm{t}=2.076 \\
\text { Sig } \mathrm{t}=0.000 \\
\mathrm{t}_{\text {tabel }}=-2.021\end{array}$ & Ha diterima \\
\hline $\begin{array}{l}\text { Variabel variance return berpengaruh negatif } \\
\text { signifikan terhadap holding period saham }(\mathrm{Y})\end{array}$ & $\begin{array}{l}\mathrm{t}=.222 \\
\mathrm{Sig}=0.006\end{array}$ & Ha ditolak \\
$\mathrm{t}_{\text {tabel }}=2.021$ & Ho diterima \\
\hline $\begin{array}{l}\text { Variabel market value berpengaruh positif } \\
\text { signifikan terhadap holding period saham (Y) }\end{array}$ & $\begin{array}{l}\mathrm{t}=.370 \\
\mathrm{Sig}=0.000\end{array}$ & Ha ditolak \\
$\mathrm{t}_{\text {tabel }}=2.021$ & Ho diterima \\
\hline $\begin{array}{l}\text { Variabel dividen pay out ratio berpengaruh } \\
\text { positif signifikan terhadap holding period } \\
\text { saham (Y) }\end{array}$ & $\begin{array}{l}\mathrm{t}=-2.052 \\
\mathrm{t}_{\text {tabel }}=-2.021\end{array}$ & Ha diterima \\
\hline
\end{tabular}

Sumber data : Data sekunder yang diolah * signifikan pada level $5 \%$

\section{PEMBAHASAN}

Hipotesis Pengaruh Serentak Variabel bid-ask spread, variance return, market value, dan dividend pay out ratio terhadap holding period.

Hasil analisis uji F pada penelitian ini menunjukkan bahwa F hitung 3.362 lebih besar dari F tabel 2.61 pada tingkat signifikansi .020 dan dapat disimpulkan bahwa secara serentak variabel bid-ask spread (X1), variance return (X2), market value (X3), dan dividend pay out ratio $(\mathrm{X} 4)$ memberikan pengaruh yang signifikan terhadap holding period $(\mathrm{Y})$.

Hal ini sesuai dengan hasil penelitian Atkins dan Dyl (1997) Amihud dan Mendelson (1986), Lenny dan Nur Indriantoro (1999) dan Subali (2000) yang menjelaskan bahwa secara secara serentak holding period.

Hipotesis Pengaruh Partial Variabel bid-ask spread, variance return, market value, dan dividend pay out ratio terhadap holding period.

Hasil analisis regresi pada penelitian ini menunjukkan bahwa dari variabel independen yaitu bid-ask spread(X1), variance return (X2), market value (X3), dan dividend pay out ratio $(\mathrm{X} 4)$ memberikan pengaruh terhadap variabel holding period $(\mathrm{Y})$. 
Nilai signifikan ini ditunjukkan dari hasil uji t yang menunjukkan nilai $\mathrm{t}$ hitung lebih besar dari $\mathrm{t}_{\text {tabel }}$ pada tingkat $\alpha=5 \%$.

\section{Variabel bid-ask spread}

Koefisien regresi untuk spread adalah positif 1.029. Hasil ini sesuai dengan teori yang menyatakan bahwa investor dengan holding period relative panjang akan mengharap Spread yang besar pula. Sedangkan tanda positif ini menunjukkan apabila Spread naik 1 satuan akan mengakibatkan naiknya holding period (masa kepemilikan) atas saham biasa sebesar 1.029 satuan, variabel yang lain dianggap konstan. Jika dilihat dari angka signifikan $\mathrm{T}$ diperoleh angka 0,045 yang menunjukan peluang kesalahan yang mungkin angka ini lebih kecil dari alpha 5\% berarti secara statistik spread mempunyai pengaruh positif signifikan dalam menentukan lamanya kepemilikan saham biasa oleh investor, sehingga Hi diterima atau menolak Ho.

Hasil penelitian ini konsistan dengan hasil penelitian Amihud dan Mendelson(1986), Atkin dan Dyl (1997), Lenny dan Indriantoro (1999) dan Maulina (2010) bahwa holding period mempunyai pengaruh positif signifikan terhadap besarnya spread saham biasa, yang berarti besarnya biaya transaksi, biaya kepemilikan dan biaya asimetri informasi merupakan salah satu faktor yang digunakan dalam pengambilan keputusan tentang panjang/pendeknya investor memegang suatu Financial Asset di Bursa Efek Indonesia.

\section{Variabel Variance Return}

Dari hasil analisis regresi diperoleh koefisien variance return sebesar .009 dengan tanda positif, artinya jika variabel yang lain dianggap tetap maka setiap ada kenaikan variance return 1 satuan maka akan diikuti dengan pertambahan masa kepemilikan pada saham biasa sebesar .009 satuan. Hasil penelitian ini bertolak belakang dengan penelitianpenelitian terdahulu, antara lain Atkin dan Dyl (1997). Variance Return menunjukkan Variabilitas return diseputar return normal yang diakibatkan adanya volatilitas saham, semakin tinggi variance return menunjukkan semakin berfariasinya retun harian yang diperoleh investor sehingga hal ini menunjukkan ketidak pastian pasar (resiko) yang tinggi, semakin tinggi tingkat resiko suatu saham maka investor akan memegang saham tersebut relatif lebih pendek dan sebaliknya semakin rendah tingkat resiko investor akan memegang saham saham tersebut relatif panjang. Hal ini dimungkinkan terjadi karena pelaku pasarnya 
tergolong investor yang menyukai risiko atau juga karena ada harapan dari investor bahwa harga saham akan terkoreksi positif.

\section{Variabel Market Value}

Dari hasil analisis regresi diperoleh koefisien market value sebesar .051 dengan tanda positif, artinya jika variabel yang lain dianggap tetap maka setiap ada kenaikan market value 1 satuan maka akan diikuti dengan pertambahan masa kepemilikan pada saham biasa sebesar .051 satuan. Hal ini sesuai dengan teori yang menyatakan bahwa investor lebih menyukai menanamkan sahamnya pada perusahaan relatif besar karena diduga mempunyai resiko yang lebih kecil serta mempunyai akses lebih besar ke pasar modal dari pada perusahaan kecil (Jogianto, 1998.) Jika dilihat dari angka signifikan T sebesar 0,370 dengan alpha 5\%, maka $\mathrm{T}$ sig $>\alpha$, sehingga Ho diterima atau menolak Hi. Dengan demikian secara statistik market value mempunyai pengaruh positif terhadap holding period tetapi tidak signifikan pada tingkat $5 \%$.

Hasil penelitian ini tidak konsisten dengan penelitian yang dilakukan sebelumnya pada Bursa Efek Jakarta oleh Maulina (2010), Lenny dan Indriantoro (1999) bahwa market value yang merupakan cerminan besarnya perusahaan adalah faktor yang paling berpengaruh terhadap keputusan investor dalam memegang saham biasa. Hal ini disebabkan karena perbedaan kondisi yang terjadi. Penelitian yang dilakukan Lenny dan Indriantoro (1999) dilakukan pada saat Indonesia belum mengalami krisis ekonomi sehingga investor dalam mengambil keputusan tentang lamanya kepemilikan atas saham biasa lebih menyukai perusahaan-perusahaan yang relative besar karena dianggap mampu mendekatkan pengharapan investor dengan yang sebenarnya terjadi. Atau dengan kata lain investor akan menahan sahamnya relative lama pada perusahaan-perusahaan yang mempunyai nilai pasar baik karena perusahaan yang besar dianggap mempunyai kestabilan yang tinggi.

Sedangkan pada kondisi krisis investor lebih condong untuk menahan kepemilikan atas sahamnya relatif pendek untuk menghindari resiko yang lebih besar yang diakibatkan oleh fluktuasi harga saham dan besarnya biaya yang harus ditanggung, baik biaya transaksi, biaya kepemilikan dan biaya asimetri informasi. Besarnya nilai market value tidak selalu mencerminkan bahwa kondisi perusahaan dalam keadaan baik tetapi 
sebaliknya besarnya market value yang diakibatkan penambahan jumlah saham yang beredar bisa menjadi sinyal negatif bahwa perusahaan mengalami kesulitan keuangan.

\section{Variabel devidend pay out ratio}

Koefisien regresi devidend pay out ratio yang ditemukan sebesar -.306 dengan tanda negatif. Hal ini berarti setiap kenaikan dividend pay out ratio sebesar 1 satuan akan berdampak pada penurunan kepemilikan saham oleh investor sebesar .306 satuan. Jika dilihat dari uji $\mathrm{T}$ diperoleh nilai signifikan $\mathrm{T}$ sebesar 0.048 lebih kecil dari alpha 5\% maka hipotesa diterima, yang berarti secara statistik devedend pay out ratio mempunyai hubungan positif dengan holding period saham biasa tetapi arah koefisiennya negatif.

Di dalam penelitian Suharsono (1999) faktor yang paling dominan dan pengambilan keputusan pembelian saham adalah harapan investor mendapat dividen yang memadai. Di dalam penelitian ini, devidend pay out ratio mempengaruhi keputusan investor untuk menahan sahamnya lebih lama namun arah koefisiennya negatif sehingga walaupun perusahaan membagikan dividen namun hal itu tidak membuat investor menahan kepemilikan saham lebih lama. Hal ini didukung oleh penelitian Mutmainnah (1999) bahwa investor tidak merespon positif pembayaran deviden yang dilakukan oleh perusahaan karena investor lebih menyukai capital gain atas saham daripada deviden.

\section{Interpretasi Koefisien Determinasi}

Koefisien determinasi digunakan untuk mengukur proporsi total variasi dependen variabel yang dijelaskan oleh independen variabel. Jika nilai koefisien determinasi ( $R$ Square) semakin mendekati angka 1, maka variabel independen secara bersama-sama mempunyai pengaruh yang kuat dalam menjelaskan variabel dependen. Sedangkan bila $\mathrm{R}$ Square mendekati 0 maka variabel independen semakin lemah dalam menjelaskan pengaruhnya terhadap variabel dependen.

Dari hasil analisis regresi diperoleh nilai R Square sebesar $27.8 \%$ yang berarti secara bersama-sama variabel bebas (bid-ask Spread, , Variance Return Market Value dan Devidend Pay Out Ratio) mampu menjelaskan variabel terikat (Holding Period) sebesar $27.8 \%$ sedangkan sisanya sebesar $72.2 \%$ dijelaskan oleh variabel lain di luar persamaan model. Berdasarkan uji F diperoleh nilai signifikan F sebesar 0,020 lebih kecil dari alpha $5 \%$. Sehingga secara statistik variabel independen dapat menjelaskan variabel dependen sebesar $27.8 \%$ dan signifikan pada taraf $5 \%$.

Variabel yang paling dominan mempengaruhi holding period saham (Y) adalah variabel bid-ask spread (X1), yang ditunjukkan dengan nilai koefisien beta yang 
distandarisasi terbesar yaitu sebesar .330. Hipotesis ini didukung oleh Sritua Arief (1993:12) yaitu: untuk menentukan variabel independen yang paling menentukan (dominan) dalam mempengaruhi nilai variabel dependen dalam suatu model regresi linear, maka gunakanlah koefisien Beta (Beta Coefficient). Koeffisien tersebut disebut standardized coefficient.

\section{SIMPULAN}

Lamanya kepemilikan investor pada saham biasa untuk perusahaan go public yang tercatat dalam JII pada tahun 2007-2010 umumnya relative pendek walaupun ada peningkatan dari nilai pasar sahamnya (market value). Secara bersama-sama variabel spread, market value, varian return dan dividend pay out ratio berpengaruh terhadap holding period atau lamanya kepemilikan saham biasa pada perusahaan go public yang tercatat dalam JII. Sedangkan secara parsial ada dua variabel yang berpengaruh signifikan terhadap lamanya kepemilikan saham biasa yaitu spread dan dividen pay out ratio dengan hubungan negatif signifikan dan spread mempunyai hubungan positif signifikan terhadap holding period pada $\alpha$ 5\%. Market value dan variance return berpengaruh terhadap holding period namun tidak signifikan pada $\alpha 5 \%$. Dari hasil penelitian menunjukkan bahwa bid-ask spread merupakan variabel paling dominan mempengaruhi. Hal ini menandakan bahwa keputusan investor untuk menahan sahamnya dalam jangka panjang atau pendek sangat dipengaruhi oleh besarnya bid-ask spread yang merupakan cerminan dari besarnya biaya transaksi, biaya kepemilikan dan biaya asimetri informasi. Kesimpulan terakhir adalah pada Bursa Efek Indonesia, faktor psikologis investor diduga merupakan faktor yang paling banyak menjadi bahan pertimbangan dalam pengambilan keputusan tentang menahan atau melepas suatu saham biasa.

\section{DAFTAR PUSTAKA}

Akhigbe, Aigbe dan Jeff Madura. 1996. Dividend policy and corporate performance, Journal of Bisiness Finance and Accounting, 23, Desember, 1267-1287.

Amihud,Yakov, dan Haim Mendelson. 1986. Asset pricing and the bid-ask spread, Journal of Financial Economics, No. 17, p. 223-249.

Atkins, Allens B. dan Edward A Dyl. 1990. Price reverals, bid-ask spread and market efficiency, Journal of Financial Quantitative Analysis, 25, 535-547.

Atkins, Allens B. dan Edward A Dyl. 1997. Market structure and rerted trading volume: Nasdaq versus the NYSE, Journal of Finance Research, Vol. XX, No. 3, p. 291304. 
Atkins, Allens B. dan Edward A Dyl. 1997. Transaction cost and holding period for common stock, Journal of Finance, Vol. III, No. 1, p. 309-320.

Brigham, Eugene,F. dan L.C. Gapenski. 1993. Intermediate Financial Management, Fifth Edition, The Dryden Press International Edition.

Corrado, Charles J., Bradford P.Jordan. 2000. Fundamentals of Invesment: Valuation and Management. The Irwin/McGraw-Hill.

Fabozzi, Frank J. 2000. Manajemen Investasi, Terjemahan, Jilid 1, 2, Penerbit Salemba Empat, Jakarta.

Hamilton, James L. 1976. Competition, scale economics and transaction cost in the stock market, Journal of Financial Quantitative Analysis, No. 9, p. 779-802.

Husnan, Suad.1998. Manajemen Keuangan Teori dan Penerapan (Keputusan Jangka Panjang), Edisi keempat, BPFE, Yogyakarta.

Investopedia. 2011. Devinition. http://www.investopedia.com diunduh tanggal 20 Agustus 2011.

Jogiyanto. 2007. Teori Portofolio dan Analisis Investasi Edisi 2007, BPFE, Yogyakarta.

Jones, Charles P. 1998. Investments, Edisi Keenam, Penerbit John Wilwey \& Sons, Inc, Toronto, Singapore.

Lenny dan N. Indriantoro. 1999. Analisa pengaruh transaction cost terhadap lamanya holding period saham biasa, Journal Bisnis dan Akuntansi, Vol 1, No. 3, p. 209220.

Maulina, Venus. 2010. Asymmetric Information Cost Dan Holding Periods Saham Biasa Di Bursa Efek Indonesia. Jurnal Iqtishoduna Vol.6 No.3 Tahun 2010.

Mitra, Devashis dan Muhammad Rasyid. 1997. The information content of divident initiation and firm size: an analysis using bid-ask spread, The Financial Review, Vol 32, No. 2, May, 309-329.

Sharpe, William. Gordon J.Alexander. Jeffry V. baily. 2005. Investasi. PT. Indeks.

Subali. 2001. Analisis pengaruh bid-ask spread, market value dan risk of return terhadap holding period saham biasa, Universitas Merdeka, Malang.

Suharsono, Judi. 1999. Pengaruh kualitas informasi pasar modal terhadap keputusan pembelian saham di kalangan investor lokal pada Galery bursa di Kotamadya Malang, Tesis, Program Pasca Sarjana Universitas Brawijaya, Malang.

Yenny, I., dan Linda. 2003. Analisis Pengaruh Bid-Ask Spread, Market Value dan Risk of Return Saham terhadap Holding Period pada Saham Terakfif yang Tercatat di Bursa Efek Jakarta Periode 200-2002, Jurnal Ventura,Vol. 6 No. 2,Agustus2003, hlm 117-126. 